\title{
Hubungan Antara External Locus of Control Dengan Kepuasan Kerja Pada Anggota Kepolisian Di Markas Polisi (Mapolda) Aceh
}

Rahmaini Fahmi

rahmainifahmi@gmail.com

Fatmawati

fatmawati@ar-raniry.ac.id
Jasmadi

jas_madi@yahoo.com

Fakultas Psikologi, Universitas Islam Negeri (UIN) Ar-Raniry Banda Aceh, Indonesia.

\begin{abstract}
Job satisfaction is one of the work variables that contribute greatly to the effectiveness of the organization and the work itself. Individual job satisfaction arises from a person's perception of how well the work provides something meaningful. On the other hand, external locus of control is a factor that influences an individual's perception of the environment, including the work environment. For this reason, this study aimed to find out how the relationship between external locus of control and job satisfaction is on Police Members at the Aceh Regional Police Headquarters. This study used a quantitative method with sampling based on simple random sampling technique. The sample in this study amounted to 287 people and the results showed that there was a relationship between external locus of control and job satisfaction on Members of the Police at the Aceh Regional Police Headquarters with Pearson correlation test values $\mathrm{r}=$ $0,232, \mathrm{p}=0,000(<0,05)$. These results indicate that there is a very significant negative relationship between external locus of control and job satisfaction on Members of the Police at the Aceh Regional Police Headquarters.
\end{abstract}

Keywords: external locus of control, job satisfaction, polri

Psikoislamika: Jurnal Psikologi dan Psikologi Islam (JPPI) Volume 16. Nomor 1. Tahun 2019. Copyright (C) 2019. Pusat Penelitian dan Layanan Psikologi.

\section{PENDAHULUAN}

Kepuasan kerja merupakan salah satu aspek pekerjaan yang penting karena berkontribusi besar terhadap efektifitas organisasi dan pada pekerjaan itu sendiri (Pratiwi, 2013). Kepuasan kerja individu muncul dari persepsi seseorang tetang bagaimana baiknya pekerjaan memberikan sesuatu yang berarti. Di sisi lain, external locus of control adalah faktor yang mempengaruhi persepsi individu terhadap lingkungannya termasuk lingkungan kerja (Kaswan, 2017).

Anggota Polri adalah pegawai negeri pada Kepolisian Negara Republik Indonesia (Undang-Undang Kepolisian Negara Republik Indonesia, 2002). Polri semakin dituntut oleh masyarakat Indonesia untuk melaksanakan tugas dan fungsinya sebagai pemelihara keamanan dan ketertiban masyarakat, sebagai penegak hukum, sebagai pelindung, pengayom dan pelayanan 
masyarakat secara profesional, transparan, responsif dan akuntabel (Nasution, 2017). Hal ini juga yang dihadapi oleh Anggota Kepolisian Negara Republik Indonesia Daerah (Polda) dalam kesehariannya, mereka dituntut berinteraksi dengan masyarakat, pandai berkomunikasi dengan rekan kerja, dan loyal terhadap atasan (Wahyurudhanto, 2018). Dari berbagai dimensi pekerjaan yang harus dijalani polisi menjadi pertimbangan untuk memutuskan merasa puas atau tidak puas terhadap profesi yang diemban (Haida \& Budiharto, 2006).

Berdasarkan informasi yang diperoleh dari Detik News mengatakan bahwa sepanjang 2017 anggota Polri Polda Aceh yang melanggar Komisi Kode Etik Polri (KKEP) naik sebanyak 27,4 persen dari tahun sebelumnya, terutama akibat meninggalkan

\section{Kepuasan Kerja}

Davis dan Keith (dalam Ruvendi, 2018) mengatakan bahwa kepuasan kerja adalah suasana psikologis tentang perasaan menyenangkan atau tidak menyenangkan terhadap pekerjaan itu sendiri. Kepuasan

\section{External Locus Of Control}

Spector (1988) menjelaskan bahwa locus of control adalah keputusan individu untuk cenderung percaya dan bertanggung jawab terhadap kejadian yang dialami berasal dari faktor internal (misalnya keterampilan, tugas (desersi). Selain itu, berdasarkan data Pemberhentian Tidak Dengan Hormat (PTDH) anggota Polri Polda Aceh tahun 2018, tercatat sebanyak 48 orang diberhentikan karena kasus desersi. Kasus di atas menunjukkan adanya permasalahan yang menyebabkan beberapa anggota kepolisian meninggalkan tugas. Meninggalkan tugas merupakan hal yang berkaitan erat dengan kepuasan kerja seseorang (Mangkunegara, 2005).

Ketidakpuasan kerja yang dirasakan seseorang dapat diungkapkan dalam berbagai cara, salah satunya adalah dengan meninggalkan pekerjaan (Robbins, 2008). Perilaku meninggalkan tugas yang dilakukan oleh anggota Polri Polda Aceh menunjukkan adanya permasalahan yang berkaitan dengan kepuasan kerja anggota Polri Polda Aceh.

berasal dari persepsi seseorang bahwa output pekerjaan (sesuatu yang diperoleh dari pekerjaan), relatif sama dengan inputnya (Kreitner, dalam Ilahi, 2017). Menurut Herzberg (dalam Gibson, 1985) kepuasan kerja merupakan perasaan puas yang dirasakan seseorang disebabkan oleh faktor pekerjaan itu sendiri

usaha, dan ketekunan) atau faktor eksternal (kesempatan, intervensi Tuhan, dan lain-lain). Rotter (dalam Davis, 2013) mendefinisikan external locus of control sebagai persepsi seseorang tentang sumber nasibnya yang meyakini bahwa suatu kejadian tidak memiliki hubungan langsung dengan tindakan yang dilakukan oleh diri sendiri dan berada di luar kontrol dirinya.

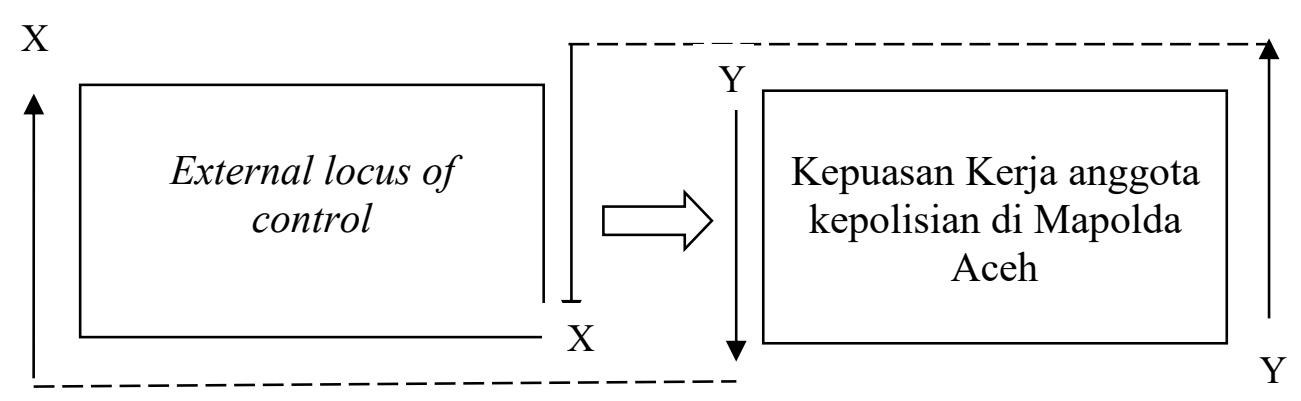

Gambar 1.1 Kerangka Konseptual 


\section{METODE}

Penelitian ini merupakan penelitian korelasional dengan satu variabel bebas, yaitu external locus of control (X) dan satu variabel terikat, yaitu kepuasan kerja (Y). Adapun yang menjadi subjek penelitian adalah anggota Kepolisian Mapolda Aceh yang sebanyak 287 orang.

Penelitian ini menggunakan kuesioner yang berbentuk skala psikologis. Skala ini disusun berdasarkan aspek kepuasan kerja yang dikemukakan oleh Herzberg (dalam Munandar, 2001) yang terdiri dari lima aspek yaitu: tanggung jawab, kemajuan, pekerjaan itu sendiri, capaian, dan pengakuan. Jumlah keseluruhan aitem pada skala ini adalah 32 pernyataan. Skala ini telah melewati uji validitas isi yang dilakukan melalui professional judgment. Setelah dilakukan uji daya beda aitem, skala kepuasan kerja menunjukkan bahwa dari 32 aitem yang diujicobakan, terdapat 26 aitem dengan

\section{HASIL}

Hasil penelitian menunjukkan bahwa terdapat hubungan antara external locus of control dengan kepuasan kerja pada anggota Kepolisian di Mapolda Aceh dengan nilai uji korelasi Pearson $\mathrm{r}=-0,232, p=0,000,(<0,05)$. Hasil ini menunjukkan bahwa terdapat hubungan negatif yang sangat signifikan antara external locus of control dengan kepuasan kerja pada anggota Kepolisian di Mapolda Aceh. External locus of control merupakan salah satu konstruk psikologi yang secara spesifik mengenai faktor eksternal atau faktor luar yang berpengaruh terhadap keberhasilan seseorang. External locus of control terdiri dari sejumlah aspek, diantaranya nasib yaitu aspek yang melihat bagaimana seseorang menganggap kesuksesan dan kegagalan yang diperoleh sudah ditakdirkan dan seseorang tidak dapat koefisien korelasi di atas 0.30 dengan rentang dari -0.389 hingga 0.776 , yang menghasilkan reliabilitas konsistensi internal kepuasan kerja sebesar 0.940 .

Skala external locus of control disusun berdasarkan aspek external locus of control yang dikemukakan oleh Rotter (dalam Davis, 2013). External locus of control ini terdiri dari empat aspek yaitu nasib, keberuntungan, sosial ekonomi, dan pengaruh orang lain. Jumlah keseluruhan aitem dalam skala ini adalah 32 pernyataan. Skala ini telah melewati uji validitas isi yang dilakukan melalui professional judgment. Setelah itu dilakukan uji daya beda aitem untuk skala external locus of control yang menunjukkan bahwa dari 36 aitem yang diujicobakan, terdapat 21 aitem dengan koefisien korelasi di atas 0.30 dengan rentang dari -0.333 hingga 0.650, yang menghasilkan reliabilitas konsistensi internal sebesar 0.872 .

merubah kembali peristiwa yang telah terjadi. Keberuntungan yaitu aspek yang melihat bagaimana seseorang menganggap bahwa setiap orang memiliki keberuntungan dan mereka sangat mempercayai apa yang mereka dapat tidak terlepas dari adanya keberuntungan yang dimiliki setiap orang. Sosial ekonomi yaitu aspek yang melihat individu yang memiliki external locus of control bersifat materialistik dan menilai orang lain berdasarkan tingkat kesejahteraan. Pengaruh orang lain yaitu aspek ini melihat individu dengan external locus of control sangat mengharapkan bantuan dari orang lain dan menganggap bahwa orang yang memiliki kekuasaan yang lebih tinggi akan mempengaruhi perilakunya.

Dari keempat aspek di atas menggambarkan bahwa individu yang 
mempercayai bahwa segala sesuatu yang dialaminya ditentukan oleh nasib atau takdir, keberuntungan, sosial ekonomi dan pengaruh orang lain cenderung merasakan kepuasan kerja yang rendah hal ini dikarenakan mereka menganggap bahwa terdapat kontrol di luar dirinya yang mendukung hasil pekerjaan yang dilakukannya. Amalini, Musadieq, dan Afrianty (2016) menemukan bahwa external locus of control berpengaruh negatif terhadap kepuasan kerja, artinya semakin rendah external locus of control seseorang maka semakin tinggi kepuasan kerjanya.

Dalam penelitian ini, peneliti melihat adanya hubungan antara external locus of control dengan kepuasan kerja pada Anggota Kepolisian di Mapolda Aceh. Hasil penelitian ini menunjukkan adanya hubungan negatif antara external locus of control dengan kepuasan kerja, artinya semakin tinggi

\section{DAFTAR PUSTAKA}

Amalini, H. F., Al Musadieq, M., \& Afrianty, T. W. (2016). Pengaruh locus of control terhadap kepuasan kerja dan kinerja (studi pada karyawan perusahaan daerah air minum (PDAM) Kota Malang). Jurnal Administrasi Bisnis, 35(1), 68-77.

Davis, G. (2013). External Locus of Control. Springer: New York.

Gibson, M. (2008). Manajemen Sumber Daya Manusia. Jakarta: Erlangga.

Haida, K. E. \& Budiharto, S. (2006). Naskah Publikasi Kepuasan Kerja Dan Burnout Pada Polisi. Yogyakarta: Universitas Islam Indonesia.

Ilahi, D. K., Mukzam, M. D., \& Prasetya, A. (2017). Pengaruh kepuasan kerja terhadap disiplin kerja dan komitmen organisasional (studi pada karyawan PT. PLN (Persero) distribusi Jawa Timur area Malang). Jurnal Administrasi Bisnis, 44(1), 31-39.

\section{KESIMPULAN}

Berdasarkan uraian di atas dapat disimpulkan bahwa hipotesis penelitian diterima yakni semakin tinggi external locus of control seseorang maka semakin rendah kepuasan kerja yang dirasakan seseorang. Begitu juga sebaliknya, apabila semakin rendah external locus of control seseorang akan diikuti dengan tingginya kepuasan kerja yang dirasakan seseorang.

external locus of control yang dirasakan oleh anggota polisi maka semakin rendah kepuasan kerja Anggota Kepolisian di Mapolda Aceh. Begitu juga sebaliknya, semakin rendah external locus of control yang dirasakan oleh anggota polisi maka semakin tinggi kepuasan yang diterima oleh anggota polisi tersebut

Kaswan. (2017). Psikologi Industri dan Organisasi. Bandung: Alfabeta

Mangkunegara, A. P. (2005). Sumber Daya Manusia Perusahaan. Remaja Rosdakarya: Bandung.

Munandar, A. S. (2001). Psikologi Industri dan Organisasi. Jakarta: Penerbit Universitas Indonesia.

Nasution, R. Z. (2017). Reformasi Birokrasi Polri Dalam Meningkatkan Kualitas Pelayanan Publik (Studi Kasus Pada Kepolisian Daerah Jawa Barat) (Tesis Tidak Dipublikasikan). UNPAS.

Pratiwi, Y. (2013). Hubungan locus of control dengan kepuasan kerja karyawan Vincent Maestro Group Surabaya [Tesis Tidak Dipublikasikan].Universitas Islam Negeri Maulana Malik Ibrahim. 
Robbins, S. P. \&Judge, T.A. (2008). Perilaku Organisasi (Organizational Behavior. Jakarta: Salemba Empat.

Ruvendi, R. (2018). Imbalan dan gaya kepemimpinan pengaruhnya terhadap kepuasan kerja karyawan di Balai Besar Industri Hasil Pertanian Bogor. Jurnal Ilmiah Binaniaga, 1(01), 17-26.

Spector, P. E. (1988). Development of the work locus of control scale. Psychological of Occupational Psychology, 61, 335-340.

Undang-Undang Kepolisian Negara Republik Indonesia, 2002.

Wahyurudhanto, A. W. A. (2018). Analisis kemampuan deteksi dini oleh bhabinkamtibmas dalam implementasi polmas sebagai penguatan program satu polisi satu desa. Jurnal Ilmu Kepolisian, 12(2), 14. 